Capel, S., Zwozdiak-Myers, P. and Lawrence, J. (2003) A study of current practice in liaison between primary and secondary schools in physical education. European Physical Education Review, 9 (2),

115-135

\title{
A study of current practice in liaison between primary and secondary schools in physical education
}

by

\section{Susan Capel, Paula Zwozdiak-Myers and Julia Lawrence}

\section{Brunel University}

Key words: contacts; liaison activities; transition; transfer from primary to secondary school

\begin{abstract}
The purpose of this study was to investigate current practice in liaison between primary and secondary schools to promote continuity and progression in physical education (PE) during the transfer of pupils from Key Stage 2 to Key Stage 3 and to identify constraints to engaging in liaison activities. A questionnaire was completed by the head of the PE department in secondary schools in five Local Education Authorities in England that received pupils from primary schools in year $7(n=80)$ and by the PE co-ordinator of the primary feeder schools of those secondary schools that responded to the questionnaire $(n=299)$. Results showed that 32 (43.8\%) secondary teachers and 157 (53.4\%) primary teachers identified that they had established contacts with their primary feeder schools or associated secondary schools respectively; and 49 (64.5\%) secondary teachers but 114 (39.6\%) primary teachers identified that currently they were engaged in liaison activities. There was a discrepancy between the percentages of teachers who indicated they had contacts with their primary feeder schools or associated secondary schools respectively, and who indicated they were engaged in liaison activities with them. These results suggested that contacts with and/or engagement in liaison activities between primary and secondary schools were not consistent across schools. A range of constraints for developing effective contacts/liaison activities were identified, with time being identified as the major constraint by both primary and secondary teachers. A range of suggestions for overcoming the constraints were also identified. These results are discussed in relation to findings from studies looking at liaison in other subjects and also in relation to the implications for schools.
\end{abstract}




\section{INTRODUCTION}

Continuity and progression are often regarded as essential components of education if pupils are to develop to their maximum potential (Birmingham Education Development Centre, 1975). Benyon (1981: 36) defined continuity as 'the transitions pupils experience from one stage of schooling to another; it can refer to the curricular experiences teachers try to provide for their pupils through a school year; and, it can refer to the transitions within a school as children move from class to class'. Progression has been defined as 'the sequence built into children's learning through curriculum policies and schemes of work so that later learning builds on knowledge, skills, understandings and attitudes learned previously' (Department of Education and Science [DES], 1990: 13). Demetriou, Goalen and Rudduck (2000) argued that the presence of continuity provides opportunities for progression, thus identifying them as linked terms. This was also a view expressed by the DES (1990: 13) who suggested that 'Continuity occurs when there is an acceptable match of curriculum and approach, allowing appropriate progression in children’s learning'.

The DES (1987) identified periods of time that require the greatest degree of continuity and progression as those that occur when pupils transfer from one school to another. In looking at the transfer from primary to secondary school ${ }^{1}$, it was recognised that 'the secondary school needs to consider how it can make the transition from primary to secondary education as smooth as possible by trying to ensure that children's personal confidence and sense of well-being are protected, and that their learning continues with the minimum of disruption' (DES, 1987: 49).

The DES (1987: 48) also stated that 'Children's development is a continuous process and schools have to provide conditions and experiences which sustain and encourage that process... If this progression is to be maintained there is a need to build systematically on the children's existing knowledge, concepts, skills and attitudes'. The introduction of the National Curriculum in England in 1988 aimed to address the issue of continuity and progression in the transfer of pupils from primary to secondary school by developing a progressive curriculum from ages 5-16 years. This was endorsed by the School Curriculum and Assessment Authority (SCAA, 1996: 4) which stated that 'the National Curriculum framework and its associated assessment arrangements are designed to promote continuity in the curriculum and in pupils' progress within and between each key stage in all subjects'.

The physical education (PE) curriculum taught in secondary schools should build on the work covered in primary schools (see, for example, Blyth and Derricott, 1985; Penney, 2001). To achieve 
such progression and continuity in the curriculum, liaison between teachers in primary and secondary schools is required. Nicholson (1990: 28) suggested that 'liaison should be approached from both the primary and secondary schools to gain insights into each other's working, but importantly, to provide a continuity in transfer'.

Research, however, suggests that liaison does not occur consistently across subjects and between all schools. In relation to liaison in science, Dawson and Shipstone (1991) found that 43 percent of secondary schools had some form of link with their primary feeder schools. They also found that no secondary school liaised with all of its primary feeder schools. Research by Featonby (1998) in one Local Education Authority (LEA) found that 20.8 percent of junior schools liaised with their secondary school. However, he also found that 98 percent of junior schools had not seen schemes of work being taught in the secondary school. He found that although secondary schools were involved in liaison with their primary feeder schools, this liaison occurred predominantly in the core subject areas of English, mathematics and science. Where liaison occurred in other subjects it was instigated by the secondary school. Reasons for lack of liaison were identified as insufficient time and finance. This reinforced the view of Lance (1994: 46) who suggested that liaison 'is one victim of the overload which has become a feature of our education system'. The National Foundation for Educational Research (NFER, 1995) suggested that one concern in the development of liaison activities was the change to funding structures in schools which had resulted in increased autonomy. As a result some schools no longer considered the establishment of links with feeder schools to be a priority. Financial implications were therefore seen to restrict some potential areas of development. Goulder, Simpson and Tuson (1995) supported this view by suggesting that the absence of financial support would limit the potential for links to be developed professionally and coherently.

Other possible reasons for lack of liaison have been identified. Walsh (1995), working with schools in Canada, suggested that the locality of the school, either within an urban or rural setting, might influence the liaison that occurs. Another factor that might influence liaison is the number of secondary schools to which primary schools send pupils and the number of primary feeder schools from which secondary schools receive pupils (SCAA, 1996). The Inner London Education Authority (ILEA, 1984: 25) noted that 'curriculum continuity, with pupils' transferring from a number of different feeder schools [to one secondary school], was another problem...'.

Thus, research has shown that liaison between schools does not occur consistently and where it does occur it is most likely to occur in the core subjects of English, mathematics and science. There is little information about liaison activities in the transfer of pupils from primary to secondary school in PE. Thus, the purpose of this study was to investigate current practice in liaison between primary and 
secondary schools to promote continuity and progression in PE during the transfer of pupils from Key Stage 2 to Key Stage 3 in England, to identify constraints for not engaging in liaison activities and suggestions of how constraints could be overcome. This information is designed to provide base-line information for future studies.

\section{METHODOLOGY}

\section{Subjects}

Schools in five LEAs in England were included in this research. These LEAs represented four county authorities and one London Borough. Within the five LEAs, all state secondary schools that had an intake of pupils from primary schools at the beginning of year 7 (the start of Key Stage 3) were included ( $n=177$ ), along with primary feeder schools of those secondary schools that completed the questionnaire ( $\mathrm{n}=538$ ). Responses were received from 80 (45\%) secondary teachers (77 teaching in mixed gender schools, 1 in a girls’ school and 2 in boys’ schools) and from 299 (56\%) primary teachers. The number of pupils on the roll of secondary schools ranged from 300 to 1850 pupils and the number of pupils on the roll of primary schools ranged from 22 to 810 pupils. The number of pupils on the roll of schools in the sample is given in Table 1.

Table 1: School roll of secondary and primary schools in the survey

\begin{tabular}{|l|l|l|l|}
\hline \multicolumn{2}{|c|}{ Secondary schools } & \multicolumn{2}{c|}{ Primary schools } \\
\hline $\begin{array}{l}\text { Number of pupils on } \\
\text { roll }\end{array}$ & $\begin{array}{l}\text { Number (and } \\
\text { percent) of schools }\end{array}$ & $\begin{array}{l}\text { Number of pupils on } \\
\text { roll }\end{array}$ & $\begin{array}{l}\text { Number (and } \\
\text { percent) of schools }\end{array}$ \\
\hline $300-699$ pupils & $14(17.5 \%)$ & 22 to 99 pupils & $68(22.7 \%)$ \\
\hline $700-1099$ pupils & $35(43.75 \%)$ & 100 to 199 pupils & $74(24.7 \%)$ \\
\hline $1100-1499$ pupils & $19(23.75 \%)$ & 200 to 299 pupils & $72(24.1 \%)$ \\
\hline $1500-1850$ pupils & $11(13.75 \%)$ & 300 to 399 pupils & $49(16.4 \%)$ \\
\hline unknown & $1(1.25 \%)$ & 400 to 499 pupils & $23(7.7 \%)$ \\
\hline & & $500-810$ pupils & $11(3.7 \%)$ \\
\hline & & unknown & $2(0.7 \%)$ \\
\hline TOTAL & $80(100 \%)$ & TOTAL & $299(100 \%)$ \\
\hline
\end{tabular}

\section{Instruments and procedures}

\section{Questionnaires}

Separate, but related, questionnaires were developed for primary and secondary schools.

Questionnaires contained a number of closed and open-ended questions related to current practice in the transfer of pupils from primary to secondary school in PE, i.e. whether, in relation to the transfer of pupils from primary to secondary school, contacts had been established between primary and secondary schools, for how long and with whom; whether schools were engaged in liaison activities; the types of liaison activities in which engaged; constraints to engaging in liaison activities; and suggestions as to how these constraints could be overcome. 
Prior to undertaking the main study, the questionnaires were piloted with a sample of 12 primary and 12 secondary teachers. As well as completing the questionnaire teachers were asked to comment on the clarity and appropriateness of the questions, instructions and accompanying letter. As a result, modifications were made to the wording of some questions, the accompanying letter and instructions for completing the questionnaire. Some changes were also made to the format and layout of the questionnaire (sub-divisions were introduced and some questions regrouped), and a further question was added asking teachers to suggest how constraints they had identified could be overcome.

Questionnaires were sent to the head of the PE department in secondary schools in March 2001. A reminder letter was sent three weeks later to those schools that had not responded, followed by another reminder letter and second questionnaire after a further four weeks. A questionnaire was sent to primary feeder schools once a secondary school had returned the questionnaire. The number of questionnaires sent to primary schools following receipt of each completed secondary school questionnaire varied according to the number of primary feeder schools associated with each secondary school. Primary schools were sent one questionnaire only, irrespective of whether they sent pupils to a number of different secondary schools. Primary school questionnaires were sent out over a six week period between May and July 2001. A reminder letter and second questionnaire was sent two weeks later to those schools that had not responded. The number of primary feeder schools from which secondary schools identified they received pupils ranged from 3 to 60 . The number of secondary schools to which primary schools identified they sent pupils ranged from 1 to 16 . Further detail about the number of schools pupils were received from or sent to is given in Table 2.

The requirements of informed consent were adhered to. A letter of consent was included with the questionnaire, along with a letter to inform the headteacher about the study. Anonymity of school and teacher was assured.

Table 2: Number and percent of schools pupils were received from or sent to

\begin{tabular}{|l|l|l|l|}
\hline \multicolumn{2}{|c|}{ Secondary schools } & \multicolumn{2}{c|}{ Primary schools } \\
\hline $\begin{array}{l}\text { Number of primary } \\
\text { feeder schools pupils } \\
\text { received from }\end{array}$ & $\begin{array}{l}\text { Number (and } \\
\text { percent) of schools }\end{array}$ & $\begin{array}{l}\text { Number of secondary } \\
\text { schools pupils sent to }\end{array}$ & $\begin{array}{l}\text { Number (and } \\
\text { percent) of schools }\end{array}$ \\
\hline $3-5$ schools & $21(26.1 \%)$ & 1 school & $68(22.7 \%)$ \\
\hline $6-10$ schools & $41(51.1 \%)$ & 2 schools & $55(18.4 \%)$ \\
\hline $11-15$ schools & $6(7.6 \%)$ & 3 schools & $52(17.4 \%)$ \\
\hline $16-30$ schools & $6(7.6 \%)$ & 4 schools & $39(13.1 \%)$ \\
\hline $31-60$ schools & $6(7.6 \%)$ & 5 schools & $27(9.0 \%)$ \\
\hline & & 6 schools & $33(11.1 \%)$ \\
\hline & & 7 to 10 schools & $15(5.0 \%)$ \\
\hline & & 11 to 16 schools & $3(1.0 \%)$ \\
\hline TOTAL & & unknown & $7(2.3 \%)$ \\
\hline & $80(100 \%)$ & TOTAL & $299(100 \%)$ \\
\hline
\end{tabular}




\section{Data analysis}

For this study quantitative data was used. Thus, answers to open-ended questions were grouped to provide quantitative data. A three-stage approach to grouping qualitative data was used. First, responses were recorded individually. From these, common areas were identified to create categories and, where appropriate, sub-divisions within categories. Individual responses were then assigned to the appropriate category. The Statistical Package for the Social Sciences (SPSS) was used to identify frequencies, means and standard deviations, where appropriate. One way Analysis of Variance was used to identify any difference between the establishment of contacts and liaison activities between primary and secondary schools and the LEA in which situated, number of pupils on the school roll and the number of schools pupils were either received from or sent to.

Not all numbers add up to 80 (secondary) or 299 (primary) because some teachers did not answer every question or they provided more than one answer to a given question.

\section{RESULTS}

\section{Contacts established between primary and secondary schools in relation to PE at Key Stages 2 and 3}

Of a total of 73 responses, 32 (43.8\%) secondary teachers indicated that contacts had been established with their primary feeder schools in relation to PE; 17 (53.1\%) with all and 15 (46.9\%) with some primary feeder schools. However, 41 (56.2\%) secondary teachers indicated that contacts had not been established with their primary feeder schools in relation to PE. Thus, only $23.3 \%$ (17) of responding secondary teachers indicated that they had established contacts with all of their primary feeder schools and 20.5\% (15) with some of their feeder primary schools.

Of the 32 secondary teachers who indicated that they had established contacts with their primary feeder schools, 27 (84.4\%) indicated that the contact was still in operation; 13 (48.1\%) with all and 14 (51.9\%) with some of their primary feeder schools, whilst 5 (15.6\%) indicated that they were no longer in contact. Thus, there had been a reduction of $5(15.6 \%)$ in terms of contacts once established to those currently in operation.

Of the 32 secondary teachers who had established contacts with their primary feeder schools, 13 (40.6\%) reported this contact to be with the PE coordinator whilst a further 7 (21.9\%) reported contact to be with the headteacher, class teacher, or a combination of PE coordinator and class teacher. The remaining teachers did not indicate with whom they had established contacts. 
Of 294 responses, 157 (53.4\%) primary teachers indicated that contacts had been established with their associated secondary schools in relation to PE; 33 (21\%) with all and 124 (79\%) with some of their associated secondary schools. However, 137 (46.6\%) primary teachers indicated that contacts had not been established with their associated secondary schools in relation to PE. Thus, only $11.2 \%$ (33) of responding primary teachers indicated that they had established contacts with all of their associated secondary schools and $42.1 \%$ (124) with some of their associated secondary schools.

Of the 157 primary teachers who indicated they had established contacts with their associated secondary schools, 134 (85.4\%) indicated that the contact was still in operation; 32 (23.9\%) with all and 102 (76.1\%) with some of their associated secondary schools, whilst 23 (14.6\%) indicated that they were no longer in contact. Thus, there had been a reduction of $23(14.6 \%)$ in terms of contacts once established to those currently in operation.

Of the 157 primary teachers who had established contacts with their associated secondary schools, 141 (89.8\%) reported this contact to be with teachers from the PE department; 1 (0.6\%) with pastoral teachers; and 6 (3.8\%) with a combination of PE and pastoral teachers. The remaining teachers did not indicate with whom they had established contacts.

Table 3 shows the length of time that contacts between primary and secondary schools had been established. Results show that some contacts had been established for several years whilst others were established more recently.

Table 3: Length of time that contacts between schools have been established

\begin{tabular}{|l|l|l|l|}
\hline \multicolumn{2}{|c|}{ Secondary schools } & \multicolumn{2}{c|}{ Primary schools } \\
\hline When contacts established & $\begin{array}{l}\text { Number (and } \\
\text { percent) of } \\
\text { schools }\end{array}$ & When contacts established & $\begin{array}{l}\text { Number (and } \\
\text { percent) of } \\
\text { schools }\end{array}$ \\
\hline Within last two years & $6(7.5 \%)$ & Within last two years & $54(18.1 \%)$ \\
\hline Within last five years & $7(8.75 \%)$ & Within last five years & $35(11.7 \%)$ \\
\hline Within last 10 years & $5(6.25 \%)$ & Within the last 10 years & $18(6.0 \%)$ \\
\hline More than 10 years ago & $4(5 \%)$ & More than 10 years ago & $9(3.0 \%)$ \\
\hline Unknown & $58(72.5 \%)$ & Unknown & $183(61.2 \%)$ \\
\hline TOTAL & $80(100 \%)$ & TOTAL & $299(100 \%)$ \\
\hline
\end{tabular}

Liaison activities between primary and secondary schools in relation to PE at Key Stages 2 and 3

Of 76 responses, 49 (64.5\%) secondary teachers indicated that currently they were engaged in liaison activities in relation to PE with their primary feeder schools; 25 (51\%) liaised with all and 24 (49\%) liaised with some of their primary feeder schools. However, 27 (35.5\%) reported that currently they 
were not engaged in any liaison activities with their primary feeder schools. Thus, only 32.9\% (25) of responding secondary teachers indicated that they were currently engaged in liaison activities in relation to PE with all and 31.6\% (24) with some of their primary feeder schools.

These figures reflect a marginal decrease when compared to liaison activities with primary feeder schools in the past. Specifically, of 70 responses 47 (67.1\%) secondary teachers indicated that they had been engaged in liaison activities in the past; of these, 21 (44.7\%) liaised with all and 26 (55.3\%) liaised with some of their primary feeder schools. A further 23 (32.9\%) secondary teachers reported that they had not been engaged in liaison activities in the past.

Of 288 responses, 114 (39.6\%) primary teachers indicated that currently they were engaged in liaison activities with their associated secondary schools in relation to PE; 32 (28.1\%) liaised with all and 82 (71.9\%) liaised with some of their associated secondary schools. However, 174 (60.4\%) reported that currently they were not engaged in any liaison activities with their associated secondary schools. Thus, only $11.1 \%$ (32) of responding primary teachers indicated that currently they were engaged in liaison activities in relation to PE with all and 28.5\% (82) with some of their associated secondary schools.

These figures reflect a marginal increase when compared to liaison activities with associated secondary schools in the past. Specifically, of 247 responses, 95 (38.5\%) primary teachers indicated that they had been engaged in liaison activities in the past; of these, 25 (26.3\%) liaised with all and 70 (73.7\%) liaised with some of their associated secondary schools. A further 152 (61.5\%) primary teachers reported that they had not been engaged in liaison activities in the past.

The range of liaison activities in which schools were currently or had been engaged are shown in Table 4. Results show that the highest percentage of primary and secondary teachers identified the liaison activities that they were engaged in as subject specific support and primary school events. The next highest percentages identified by secondary teachers were induction days, PE days, extracurricular activities and Continuing Professional Development (CPD), whereas the next highest percentages identified by primary teachers were meetings, induction days, PE days, extra-curricular activities and CPD, respectively.

Table 4: Range of liaison activities identified by secondary and primary schools to promote continuity and progression in PE

\begin{tabular}{|l|l|l|l|}
\hline \multicolumn{2}{|c|}{ Secondary schools } & \multicolumn{2}{c|}{ Primary schools } \\
\hline $\begin{array}{l}\text { No. } \\
(\%)\end{array}$ & Type of activity & $\begin{array}{l}\text { No. } \\
(\%)\end{array}$ & Type of activity \\
\hline $\begin{array}{l}29 \\
(27.9)\end{array}$ & Subject specific support, e.g. PE & $\begin{array}{l}120 \\
(36.5)\end{array}$ & primary school events, e.g. festivals, \\
\hline
\end{tabular}




\begin{tabular}{|c|c|c|c|}
\hline & $\begin{array}{l}\text { lessons taught predominantly by } \\
\text { secondary specialist staff, either at the } \\
\text { primary or secondary school site; } \\
\text { support also provided through } \\
\text { secondary school pupils being } \\
\text { involved in Leadership Award } \\
\text { initiatives (CSLA, JSLA and } \\
\text { Millennium Volunteers) }\end{array}$ & & $\begin{array}{l}\text { tournaments, sports days and TOPS } \\
\text { programmes - either by providing specialist } \\
\text { support or organising entire events }\end{array}$ \\
\hline $\begin{array}{l}20 \\
(19.2)\end{array}$ & $\begin{array}{l}\text { primary school events, e.g. festivals, } \\
\text { tournaments, sports days and TOPS } \\
\text { initiatives - either by providing } \\
\text { specialist support or organising entire } \\
\text { events }\end{array}$ & $\begin{array}{l}61 \\
(18.5)\end{array}$ & $\begin{array}{l}\text { Subject specific support, e.g. PE lessons } \\
\text { taught predominantly by secondary specialist } \\
\text { staff, either at the primary or secondary school } \\
\text { sites; support also provided through secondary } \\
\text { school Leadership Award initiatives from } \\
\text { CSLA and JSLA pupils }\end{array}$ \\
\hline $\begin{array}{l}16 \\
(15.4)\end{array}$ & $\begin{array}{l}\text { induction days, e.g. } 1 / 2 \text { days or taster } \\
\text { sessions at the secondary school; not } \\
\text { necessarily orientated to PE although } \\
\text { sample lessons often included in the } \\
\text { programme }\end{array}$ & $\begin{array}{l}41 \\
(12.5)\end{array}$ & Meetings, e.g. engaged in joint meetings \\
\hline $\begin{array}{l}13 \\
(12.5)\end{array}$ & $\begin{array}{l}\text { Physical Education days, e.g. } 1 / 2 \\
\text { days held at the secondary school; } \\
\text { usually during the summer term and } \\
\text { linked with pupils following } \\
\text { Leadership Awards }\end{array}$ & $\begin{array}{l}35 \\
(10.6)\end{array}$ & $\begin{array}{l}\text { induction days, e.g. } 1 / 2 \text { days or taster } \\
\text { sessions at the secondary school; not } \\
\text { necessarily orientated towards PE although } \\
\text { sample lessons often included within the } \\
\text { programme }\end{array}$ \\
\hline $\begin{array}{l}12 \\
(11.5)\end{array}$ & $\begin{array}{l}\text { extra-curricular opportunities held } \\
\text { at either the primary or secondary } \\
\text { school site; predominantly organised } \\
\text { by secondary specialist staff with the } \\
\text { support of their Leadership Award } \\
\text { pupils; also joint fixtures between } \\
\text { Year } 6 \text { and Year } 7 \text { team players }\end{array}$ & $\begin{array}{l}32 \\
(9.7)\end{array}$ & $\begin{array}{l}\text { Physical Education days, e.g. 1/2 days held } \\
\text { at the secondary school; usually during the } \\
\text { summer term and linked with pupils' } \\
\text { following Leadership Awards }\end{array}$ \\
\hline $\begin{array}{l}8 \\
(7.7)\end{array}$ & $\begin{array}{l}\text { CPD, e.g. providing or supporting } \\
\text { CPD training initiatives }\end{array}$ & $\begin{array}{l}22 \\
(6.7)\end{array}$ & $\begin{array}{l}\text { extra-curricular opportunities held at either } \\
\text { the primary or secondary school sites; } \\
\text { predominantly organised by secondary } \\
\text { specialist staff with the support of their } \\
\text { Leadership Award pupils; also joint fixtures } \\
\text { between Year } 6 \text { and Year } 7 \text { teams }\end{array}$ \\
\hline $\begin{array}{ll}5 \\
(4.8)\end{array}$ & $\begin{array}{l}\text { Meetings, e.g. engaged in joint } \\
\text { meetings }\end{array}$ & $\begin{array}{l}17 \\
(5.2)\end{array}$ & $\begin{array}{l}\text { CPD, e.g. provision or support of CPD } \\
\text { initiatives }\end{array}$ \\
\hline $\begin{array}{l}1 \\
(1.0)\end{array}$ & Community links & $1(0.3)$ & Community links \\
\hline $\begin{array}{ll}104 \\
(100 \%)\end{array}$ & Total & $\begin{array}{l}329 \\
(100 \%)\end{array}$ & Total \\
\hline
\end{tabular}

Results of one way Analysis of Variance showed no significant difference in contacts or engagement in liaison activities between secondary schools and their primary feeder schools or between primary schools and their associated secondary school in relation to LEA in which situated, number of pupils on the school roll and number of schools pupils were either received from or sent to. 


\section{Constraints to the development of liaison activities in relation to PE at Key Stages 2 and 3 and suggestions for overcoming the constraints}

Of 74 responses, 65 (87.8\%) secondary teachers indicated that there were constraints to the promotion of liaison activities in relation to PE in the transfer of pupils from primary to secondary school, resulting in 143 constraints being identified, grouped into nine categories. Nine (12.2\%) reported that there were no constraints.

Of 270 responses, 208 (77\%) primary teachers indicated that there were constraints to the promotion of liaison activities in relation to PE in the transfer of pupils from primary to secondary school, resulting in 404 constraints being identified, grouped into nine categories. Sixty-two (23\%) reported that there were no constraints.

The range of constraints identified in relation to the development of liaison activities in the transfer of pupils from primary to secondary school in PE are shown in Table 5. The table shows that the highest percentage of both primary and secondary teachers identified the allocation of time for PE, in terms of curriculum hours and non-contact time for planning purposes, as the biggest constraint to the further development of liaison activities. The next highest percentage of secondary teachers identified curriculum issues at Key Stages 2 and 3 as a constraint, yet a low percentage of primary teachers identified curriculum issues as a constraint. Similar differences in percentages can be found with respect to the need for relevant transfer documentation and primary teachers' subject knowledge and expertise. On the other hand, a higher percentage of primary teachers than secondary teachers identified as constraints differences between primary schools in terms of size, location and number of different primary schools that secondary schools receive pupils from, meetings, primary school staff issues, resources and the status and profile of primary PE.

Table 5: Constraints identified to the development of liaison activities to promote continuity and progression in PE between primary and secondary schools

\begin{tabular}{|c|l|l|l|}
\hline \multicolumn{2}{|c|}{ Secondary schools } & \multicolumn{1}{c|}{ Primary schools } \\
\hline $\begin{array}{c}\text { No. } \\
(\%)\end{array}$ & \multicolumn{1}{|c|}{ Type of constraint } & $\begin{array}{l}\text { No. } \\
(\%)\end{array}$ & \multicolumn{1}{c|}{ Type of constraint } \\
\hline $35(24.4)$ & $\begin{array}{l}\text { time allocation for PE, planning and } \\
\text { non-contact time }\end{array}$ & $\begin{array}{l}131 \\
(32.4)\end{array}$ & $\begin{array}{l}\text { time allocation for PE, planning and non- } \\
\text { contact time }\end{array}$ \\
\hline 25 (17.5) & $\begin{array}{l}\text { curriculum issues about both Key } \\
\text { Stages 2 and 3 - including the range } \\
\text { of activities, variety, standards, } \\
\text { levels and expectations }\end{array}$ & 63 & $\begin{array}{l}\text { Meetings, e.g. opportunities for liaison } \\
\text { activities, communication, meetings and } \\
\text { discussions }\end{array}$ \\
\hline $16(11.2)$ & $\begin{array}{l}\text { Meetings, e.g. opportunities for } \\
\text { liaison activities, communication, } \\
\text { meetings and discussions }\end{array}$ & $\begin{array}{l}(15.6) \\
13.7)\end{array}$ & $\begin{array}{l}\text { Primary school staff issues, e.g. conflicting } \\
\text { pressures and priorities impacting on primary } \\
\text { school staff; issues of continuity with respect } \\
\text { to staff turnover and staffing issues in general }\end{array}$ \\
\hline
\end{tabular}




\begin{tabular}{|c|c|c|c|}
\hline $15(10.5)$ & $\begin{array}{l}\text { transfer documentation; lack of } \\
\text { relevant, useful knowledge and } \\
\text { information; pupils’ records, and the } \\
\text { number of primary feeder schools } \\
\text { using different procedures }\end{array}$ & \begin{tabular}{|l|}
47 \\
$(11.6)$
\end{tabular} & $\begin{array}{l}\text { resources, facilities and funding: equipment, } \\
\text { transportation }\end{array}$ \\
\hline $15(10.5)$ & $\begin{array}{l}\text { Primary teachers' subject } \\
\text { knowledge and expertise at Key } \\
\text { Stage } 2\end{array}$ & $\begin{array}{l}45 \\
(11.1)\end{array}$ & $\begin{array}{l}\text { Differences between primary schools, e.g. } \\
\text { size and location of school; also, number of } \\
\text { different primary schools that secondary } \\
\text { schools receive pupils from, in Year } 7\end{array}$ \\
\hline $\begin{array}{l}14 \\
(9.8)\end{array}$ & $\begin{array}{l}\text { Primary school staff issues, e.g. } \\
\text { conflicting pressures and priorities } \\
\text { impacting on primary school staff; } \\
\text { issues of continuity with respect to } \\
\text { staff turnover and staffing issues in } \\
\text { general }\end{array}$ & $\begin{array}{l}23 \\
(5.7)\end{array}$ & $\begin{array}{l}\text { the status and profile of PE in primary } \\
\text { schools: peripheral position, motivation and } \\
\text { incentive of primary staff }\end{array}$ \\
\hline $12(8.4)$ & resources, facilities and funding & $\begin{array}{l}21 \\
(5.2) \\
\end{array}$ & $\begin{array}{l}\text { Primary teachers' subject knowledge and } \\
\text { expertise at Key Stage } 2\end{array}$ \\
\hline $7(4.9)$ & $\begin{array}{l}\text { Differences between primary } \\
\text { schools, e.g. size and location of } \\
\text { primary feeder schools; also, the } \\
\text { number of different primary schools } \\
\text { that secondary schools receive } \\
\text { pupils from, in Year } 7\end{array}$ & $\begin{array}{l}15 \\
(3.7)\end{array}$ & $\begin{array}{l}\text { curriculum issues about both Key Stages } 2 \\
\text { and } 3 \text { - including the range of activities, } \\
\text { variety, standards, levels and expectations }\end{array}$ \\
\hline $4(2.8)$ & $\begin{array}{l}\text { the status and profile of PE within } \\
\text { the primary feeder schools }\end{array}$ & $\begin{array}{l}4 \\
(1.0)\end{array}$ & $\begin{array}{l}\text { transfer documentation: lack of relevant, } \\
\text { useful knowledge and information; pupils' } \\
\text { records, and the number of schools using } \\
\text { different procedures }\end{array}$ \\
\hline $\begin{array}{l}143 \\
(100 \%)\end{array}$ & Total & $\begin{array}{l}404 \\
(100 \%)\end{array}$ & Total \\
\hline
\end{tabular}

Fifty-nine (73.7\%) secondary teachers and 110 (36.8\%) primary teachers made suggestions about how the constraints to the development of liaison activities could be overcome. This resulted in 129 suggestions being made by secondary teachers and 193 suggestions by primary teachers. For comparison these suggestions have been categorised into groupings similar to those used for identifying constraints. These suggestions are shown in Table 6. The suggestion of how constraints could be overcome identified by the highest percentage of secondary teachers was the need to provide training opportunities to address primary teachers' subject knowledge and expertise, followed by engaging in more cross-phase meetings, more time allocation for PE, and the need to look more closely at curriculum issues in relation to Key Stage 2 and Key Stage 3. The suggestion identified by the highest percentage of primary teachers was the need to engage in more cross-phase meetings, followed by an increase in time allocation for PE, increased resources, and the need to provide training opportunities to address primary teachers' subject knowledge and expertise. Differences in percentages of primary and secondary teachers who identified suggestions were most marked in relation to the need to: increase resources; increase training opportunities to address primary teachers' subject knowledge and expertise; address curriculum issues in relation to Key Stages 2 and 3; and review transfer documentation. 
Table 6: Suggestions for overcoming constraints to the development of liaison activities to promote continuity and progression in PE between primary and secondary schools

\begin{tabular}{|c|c|c|c|}
\hline \multicolumn{2}{|r|}{ Secondary schools } & \multicolumn{2}{|r|}{ Primary schools } \\
\hline $\begin{array}{l}\text { No. } \\
\text { (\%) }\end{array}$ & $\begin{array}{l}\text { Suggestion of how to overcome } \\
\text { constraints }\end{array}$ & $\begin{array}{l}\text { No. } \\
\text { (\%) }\end{array}$ & $\begin{array}{l}\text { Suggestion of how to overcome } \\
\text { constraints }\end{array}$ \\
\hline $\begin{array}{l}33 \\
(25.6)\end{array}$ & $\begin{array}{l}\text { Provide training opportunities to develop } \\
\text { primary teachers' subject knowledge and } \\
\text { expertise at Key Stage 2; provide CPD } \\
\text { opportunities; make more use of PE } \\
\text { specialists; provide more support to primary } \\
\text { feeder schools; offer more taster sessions; } \\
\text { engage in more team teaching and } \\
\text { discussions }\end{array}$ & $\begin{array}{l}53 \\
(27.5)\end{array}$ & $\begin{array}{l}\text { Increase meetings, including structured } \\
\text { meeting opportunities to provide opportunities } \\
\text { for liaison activities, communication and } \\
\text { discussion with associated secondary schools }\end{array}$ \\
\hline $\begin{array}{l}32 \\
(24.8)\end{array}$ & $\begin{array}{l}\text { Increase meetings, including structured } \\
\text { meeting opportunities to provide } \\
\text { opportunities for liaison activities, } \\
\text { communication and discussion with primary } \\
\text { feeder schools }\end{array}$ & $\begin{array}{l}40 \\
(20.7)\end{array}$ & $\begin{array}{l}\text { Increase time, e.g. address the time allocation } \\
\text { for PE in the curriculum; provide more time for } \\
\text { planning and non-contact initiatives }\end{array}$ \\
\hline $20(15.5)$ & $\begin{array}{l}\text { Increase time, e.g. address the time } \\
\text { allocation for PE within the curriculum; } \\
\text { provide more time for planning and non- } \\
\text { contact initiatives }\end{array}$ & $\begin{array}{l}38 \\
(19.7)\end{array}$ & $\begin{array}{l}\text { Increase resources, including increasing } \\
\text { funding for equipment and transportation costs, } \\
\text { increasing facilities, increasing supply cover }\end{array}$ \\
\hline $17(13.2)$ & $\begin{array}{l}\text { Evaluate curriculum, e.g. address } \\
\text { curriculum issues relating to Key Stage } 2 \\
\text { and Key Stage } 3 \text { in terms of range, variety, } \\
\text { standards, levels and expectations }\end{array}$ & $\begin{array}{l}27 \\
(14.0)\end{array}$ & $\begin{array}{l}\text { Provide training opportunities to develop } \\
\text { primary teachers' subject knowledge and } \\
\text { expertise at Key Stage 2: provide CPD } \\
\text { opportunities; make more use of PE specialists; } \\
\text { provide more support to primary schools; offer } \\
\text { more taster sessions; engage in more team } \\
\text { teaching and discussions; invest in training } \\
\text { students in initial teacher education }\end{array}$ \\
\hline $\begin{array}{l}9 \\
(7.0)\end{array}$ & $\begin{array}{l}\text { Review transfer documentation, e.g. } \\
\text { improve records of pupils, develop } \\
\text { common transfer documentation (as } \\
\text { number of primary feeder schools using } \\
\text { different procedures) to address lack of } \\
\text { knowledge }\end{array}$ & $\begin{array}{l}14 \\
(7.2)\end{array}$ & $\begin{array}{l}\text { Increase status of primary PE, e.g. redress } \\
\text { the current status and profile of PE in primary } \\
\text { schools }\end{array}$ \\
\hline $\begin{array}{l}9 \\
(7.0)\end{array}$ & $\begin{array}{l}\text { Increase resources, including increasing } \\
\text { funding for equipment and transportation } \\
\text { costs, increasing facilities, increasing } \\
\text { supply cover }\end{array}$ & $\begin{array}{l}11 \\
(5.7)\end{array}$ & $\begin{array}{l}\text { Evaluate curriculum, e.g. address curriculum } \\
\text { issues relating to Key Stage } 2 \text { and Key Stage } 3 \\
\text { in terms of range, variety, standards, levels and } \\
\text { expectations }\end{array}$ \\
\hline $\begin{array}{l}6 \\
(4.6)\end{array}$ & $\begin{array}{l}\text { Increase status of primary PE, e.g. } \\
\text { redress the current status and profile of PE } \\
\text { in primary schools }\end{array}$ & $\begin{array}{l}9 \\
(4.7)\end{array}$ & $\begin{array}{l}\text { Reduce primary schools staff issues, e.g. } \\
\text { reduce conflicting pressures so can prioritise } \\
\text { PE, address staffing issues and rate of staff } \\
\text { turnover in primary schools }\end{array}$ \\
\hline $\begin{array}{l}3 \\
(2.3)\end{array}$ & $\begin{array}{l}\text { Reduce primary schools staff issues, e.g. } \\
\text { reduce conflicting pressures so can } \\
\text { prioritise PE, address staffing issues and } \\
\text { rate of staff turnover in primary schools }\end{array}$ & $\begin{array}{l}1 \\
(0.5)\end{array}$ & $\begin{array}{l}\text { Review transfer documentation, e.g. improve } \\
\text { records of pupils, develop common transfer } \\
\text { documentation (as number of primary feeder } \\
\text { schools using different procedures) to address } \\
\text { lack of knowledge }\end{array}$ \\
\hline $\begin{array}{l}129 \\
(100 \%)\end{array}$ & Total & $\begin{array}{l}193 \\
(100 \%)\end{array}$ & Total \\
\hline
\end{tabular}

\section{DISCUSSION}


Results from this study must be treated with caution due to certain limitations of the study and of the questionnaire. It is not clear whether teachers interpreted questions in the same way. For example, it is not clear whether teachers interpreted the words contact with and liaison activities in the same way or whether they shared the same understanding of the key terms continuity, progression and transition which were used extensively throughout the questionnaire. Further, the size of the overall sample was relatively small, with a limited number of responses to some questions, which makes generalisations to other schools tenuous. Nevertheless, the results suggest some interesting findings in relation to current practice in transfer from primary to secondary school (from Key Stage 2 to Key Stage 3) in PE to provide base-line data for future studies.

Thirty-two (43.8\%) secondary teachers and 157 (53.4\%) primary teachers indicated that they had established contacts with their primary feeder schools or associated secondary schools respectively in relation to PE. However, 17 (23.3\%) secondary teachers and 33 (11.2\%) primary teachers identified that they had established contacts with all and 15 (20.5\%) and 124 (42.1\%) with some of their primary feeder schools or associated secondary schools, respectively. Further, 41 (56.2\%) secondary teachers and 137 (46.6\%) primary teachers indicated that no contacts had been made.

Forty-nine (64.5\%) secondary teachers but 114 (39.6\%) primary teachers indicated that currently they were engaged in liaison activities in relation to PE with their primary feeder schools or associated secondary schools respectively. However, 25 (32.9\%) secondary teachers and 32 (11.1\%) primary teachers indicated that currently they were engaged in liaison activities with all and 24 (31.6\%) and 82 (28.5\%) with some of their primary feeder schools or associated secondary schools, respectively. Twenty-seven (35.5\%) secondary teachers but 174 (60.4\%) primary teachers indicated that currently they were not engaged in liaison activities. Further, results suggested that the percentage of primary schools engaged in liaison activities has marginally increased (from 38.5\% to 39.6\% of responding schools), but the percentage of secondary schools engaged in liaison activities has marginally decreased (from $67.1 \%$ to $64.5 \%$ of responding schools).

There was a mixed picture in relation to the percentage of teachers who identified that they had contacts with and were engaged in liaison activities with their primary feeder schools or associated secondary schools. A lower percentage $(43.8 \%$; 32$)$ of secondary teachers reported that they had contacts with their primary feeder schools than primary teachers $(53.4 \%$; 157$)$ reported that they had with their associated secondary schools. However, a higher percentage (64.5\%; 49) of secondary teachers reported they were engaged in liaison activities with their primary feeder schools than primary teachers $(39.6 \%$; 114$)$ reported that they were engaged in liaison activities with their associated secondary schools. Reasons for the difference in percentage of primary and secondary 
teachers who identified that they had contacts with/were engaged in liaison activities are not clear, but it may be due, at least in part, to how liaison activities are perceived and/or established and how teachers prioritise the demands made on them in relation to wider issues, as shown by the percentage of primary and secondary teachers who identified various constraints to developing liaison activities. In a study of curriculum liaison between schools in one LEA, Featonby (1998) found that liaison between secondary and primary schools occurred mainly when it was initiated by secondary schools. Further, Lance (1994: 46) suggested that 'Given their more flexible budgets and more favourable staffing levels, secondary schools are often the initiators of link programmes...'. The expertise of secondary subject specialists is a consideration here for initiating liaison activities. Further research of a qualitative nature is needed to establish reasons for differences between primary and secondary schools in establishing contacts/liaison activities and also into how contacts/liaison activities are established and subsequently developed.

There was a discrepancy between the percentage of teachers who indicated they had contacts with their primary feeder schools and associated secondary schools respectively and the percentage that indicated they undertake liaison activities with them. A higher percentage (64.5\%; 49) of secondary teachers identified that they were engaged in liaison activities than identified that they had contacts with their primary feeder schools (43.8\%; 32), whilst a higher percentage (53.4\%; 157) of primary teachers identified that they had established contacts with their associated secondary schools than were engaged in liaison activities (39.6\%; 14). The reason for the finding in relation to secondary schools is not clear as it would seem that to be engaged in liaison activities requires contacts to have been made. In addition, reasons for differences in findings between primary and secondary schools are not clear. However, there are a number of possible reasons for these differences, including secondary schools initiating and taking a more active role in developing contacts and establishing liaison activities with their feeder primary schools. This may be because of the way staffing in secondary schools is organised, which allows them to allocate this role to one member of staff, whereas in primary schools staff may each have a number of responsibilities and liaison in relation to PE with associated secondary schools is not a priority and/or because secondary school teachers receive pupils in year 7 from a number of different primary schools. Thus, further research is needed to investigate reasons why a higher percentage of secondary teachers identified that they had engaged in liaison activities than had established contacts and reasons for differences in findings between primary and secondary teachers.

These results suggested there was no consistency in the establishment of contacts and/or engagement in liaison activities between primary and secondary schools. This is consistent with findings of studies in other subjects. For example, Dawson and Shipstone (1991) found that 43 percent of 
secondary schools had some form of liaison with their primary feeder schools in science and Featonby (1998) found that 20.8 percent of junior schools liaised with their secondary schools. As research has suggested that contacts with/liaison between schools is better in the core subjects of English, mathematics and science, the results of the present study in PE are encouraging. However, if contacts and liaison are required to promote curriculum continuity and progression to enhance pupils' learning and enable standards of attainment to rise in PE, these results suggested that such an aim may not have been achieved consistently across all schools involved in this study.

Thirteen (40.6\%) secondary teachers identified that they had established contact with the PE coordinator in their primary feeder schools, although 7 (21.9\%) had established contact with other primary school staff, such as the headteacher or the class teacher. On the other hand, 14 (89.8\%) primary teachers identified that they had established contact with secondary school PE staff. This finding was anticipated due to the organisation of primary and secondary schools. Secondary school PE staff would be expected to coordinate any liaison activities in relation to PE, whereas liaison activities in relation to PE may be coordinated by a number of different staff in primary schools. However, this finding shows the importance of ensuring contact with the right person. These findings support those of Dawson and Shipstone (1991) in science where they found that liaison usually involved the Head of Department.

Results showed a difference in the length of time contacts had been established. Some had been established for a period of time, others more recently. Results showed that 6 (7.5\%) secondary teachers and 54 (18.1\%) primary teachers reported that contacts had been established within the last 2 years. Reasons for these findings are not clear. Dawson and Shipstone (1991) found that there had been an increase in liaison in science since the 1980s, whilst Jarman (1997), looking at continuity in science in Northern Ireland, found that since the introduction of the National Curriculum there had been an increase in liaison activities between primary and secondary schools. Although the introduction of the National Curriculum may have been helpful in promoting contact between schools it seems that, in PE at least, contacts were not established by many of these schools at the time of the introduction of the National Curriculum. One secondary teacher indicated that contacts, including length of contacts, varied with different primary feeder schools - some had been in operation for several years, others were transient and others were non-existent, suggesting differences in contacts between different primary feeder schools involved in the transfer of pupils to the same secondary school. This finding needs to be followed up with other schools to identify if there are different practices with different schools from whom pupils are received/sent to. It is also important to find out more about how long contacts remain in place and how effective these contacts are. 
Results suggested that there was a reduction in contacts/engagement in liaison activities after they were established and that not all contacts/liaison activities remained operational. Reasons for this are not clear from the results of this study although some possible reasons include changes of staff in schools - with new staff not maintaining contacts/liaison activities already established; contacts/liaison activities not being prioritised by staff (which may be a result of the low profile given to PE in some schools); pressures on staff resulting in lack of time to maintain/develop contacts/liaison activities; and financial constraints. Further research is therefore needed to consider why contacts/liaison activities are not maintained and whether anything can be done to overcome this.

Many ways in which contacts/liaison activities had been established were identified, including specific liaison meetings, through visits to secondary schools - usually by primary headteachers, induction days (for year 6 pupils visiting secondary schools), parent interviews and through secondary schools providing specialist assistance to primary schools. These reflect the findings of the NFER (1995) report into continuity and progression which found that there was a range of ways in which contacts between schools were established.

A range of liaison activities were identified as being undertaken, including: secondary school staff teaching PE lessons in primary schools; involving secondary school pupils taking Leadership Awards working in primary schools; primary schools events such as festivals, tournaments, sports days etc. organised or supported by secondary staff; induction and/or PE days; extra-curricular opportunities; and CPD. Given that lack of time and funding were identified as constraints - perhaps certain liaison activities are more attractive/viable if both primary and secondary schools perceive that they might benefit. The use of secondary pupils on Community Sports Leaders Awards (CSLA), Junior Sports Leaders Awards (JSLA) and Millennium Volunteer (MV) programmes may be a means by which both primary and secondary schools gain from the experience. Further research is needed to find out why specific liaison activities are selected, the purpose of each activity and how effective each activity is.

A range of constraints to developing contacts/liaison activities were identified. Time was identified as the major constraint by the highest percentage of both primary and secondary teachers - including teaching hours and non-contact time for planning purposes. In addition, other constraints identified, such as conflicting pressures and lack of opportunities, may be related to lack of time. This finding supports results of other work that has identified lack of time as a reason for not developing liaison between schools (for example, Dawson and Shipstone, 1991; Doyle and Herrington, 1998; Goulder et al., 1995; Featonby, 1998). 
There were differences in the percentage of primary and secondary teachers who identified other constraints. A higher percentage of secondary teachers identified curriculum issues at Key Stages 2 and 3, transfer documentation and primary teachers' subject knowledge and expertise, as constraints than primary teachers; and a higher percentage of primary teachers identified meetings, primary school staff issues, resources and differences between primary schools in terms of size, location and number of different primary schools that secondary schools receive pupils from, as constraints than secondary teachers. Lack of resources reflects findings by NFER (1995) and Goulder et al. (1995) who both suggested that financial aspects would hinder the development of liaison activities between primary and secondary schools. Further, ILEA (1984) and SCAA (1996) suggested that the number of secondary schools to which primary schools send pupils and the number of primary feeder schools from which secondary schools receive pupils might influence liaison activities. However, constraints identified by primary teachers in this study due to differences of size, location and number of different primary schools that secondary schools receive pupils from, were not supported by results of Analysis of Variance which found no significant difference between whether contacts/liaison activities were developed between primary and secondary schools and the number of pupils on the school roll or number of schools pupils were either received from or sent to. Further, in this study no differences were found between schools in different LEAs. However, this study did not consider other factors which may be relevant, for example, whether schools were in a rural or urban location. Further research is needed to determine reasons for differences in perception of constraints between primary and secondary teachers and whether they are related to different priorities between primary and secondary schools.

Results showed that the suggestions for overcoming constraints identified by the highest percentage of primary and secondary teachers differed. The suggestion identified by the highest percentage of secondary teachers was to provide training opportunities to develop primary teachers' subject knowledge and expertise at Key Stage 2, whereas for primary teachers it was to increase meetings to provide structured opportunities for liaison activities and discussion with associated secondary schools. However, the need to provide training opportunities to address primary teachers' subject knowledge and expertise, engaging in more cross-phase meetings and more time allocation for PE were identified by a high percentage of both primary and secondary teachers. Reasons for differences may be that primary teachers do not regard PE as a priority therefore consider training in other subject areas as more important. Meetings may be perceived as a more realistic option for gaining the knowledge or information they require in PE. Further research is needed to look at reasons for these findings and also question whether it is feasible to build on these suggestions to promote better contacts/liaison activities between primary and secondary schools in relation to $\mathrm{PE}$ in the transfer from Key Stage 2 to Key Stage 3. 


\section{CONCLUSION}

The findings from this study provide a broad overview of what these primary and secondary schools were doing in relation to developing and/or maintaining contacts/liaison activities to enable continuity and progression to occur in PE in the transition from Key Stage 2 to Key Stage 3. However, they do not provide specific details about these contacts/liaison activities. More information is needed about contacts/liaison activities in individual schools in terms of the purposes for establishing contacts and undertaking specific liaison activities. Without more information it is not possible to make recommendations about what works and what does not work. Despite this, secondary schools and their primary feeder schools need to establish what is feasible and realistic for them to do in order to promote continuity and progression in the PE curriculum. Success can only be achieved if schools recognise the importance of establishing liaison activities which make a difference to pupils, and that they have the time and resources to carry them out.

The findings of this study suggest several areas for future research, some of which have been identified in the discussion, including research to identify reasons for differences between perceptions of primary and secondary teachers in establishing contacts and/or engaging in liaison activities; why primary and secondary teachers identified different constraints and whether these are associated with different priorities between primary and secondary teachers; and why there are differences in suggestions of ways to overcome constraints. Other areas of research include case studies of a small number of schools - to look at, for example, whether there is any consistency in contacts and liaison activities across schools from which pupils are received or are sent to. Further research needs to be undertaken to examine reasons why and how specific contacts/liaison activities are established, for what purpose, how effective they are in achieving their purpose and why they are maintained or cease to function. A longitudinal study would also enable information to be gained on whether and how contacts and liaison activities, once established, are maintained and for how long or why they are not maintained.

\section{Notes:}

${ }^{1}$ The majority of schools in England are organised as primary (ages 5-11 years), which are normally split into infant (ages 5-7 years) and junior (ages 7-11 years); and secondary (ages 11-16 or 11-18 years). Infant aligns with Key Stage 1 and junior with Key Stage 2 of the National Curriculum and secondary schools with Key Stage 3 (11-14 years) and Key Stage 4 (14-16 years, i.e. the end of compulsory schooling).

\section{REFERENCES}

Benyon, L. (1981) ‘Curriculum Continuity’, Education 3-13 9(2): 36-41. 
Birmingham Education Development Centre (1975) Continuity in Education: Junior to Secondary. Final Report. Birmingham: City of Birmingham Education Department.

Blyth, A. and Derricott, R. (1985) 'Continuity and Discontinuities in the Primary Curriculum', Curriculum 6(2): 19-24.

Dawson, R. and Shipstone, D. (1991) 'Liaison in Science at the Primary/Secondary Interface', School Science Review 72(261): 17-25.

Demetriou, H., Goalen, P. and Rudduck, J. (2000) 'Academic Performance, Transfer, Transition and Friendship: Listening to the Student Voice’, International Journal of Educational Research 33: 425441.

Department of Education and Science (DES) (1987) The Curriculum from 5 to 16. Curriculum Matters 2. London: Her Majesty’s Stationery Office.

Department of Education and Science (DES) (1990) Starting with Quality: Report of the Committee of Enquiry into the Quality of Educational Experiences Offered to 3-4 year Olds. London: HMSO.

Doyle, L. and Herrington, N. (1998) 'Learning Progression Across the Primary/Secondary Divide’, All in Success 9(2): 10-12.

Featonby, D.R. (1998) 'A Report on Curriculum Liaison Between Junior and Secondary Schools in County Durham (1997)’, Curriculum 19(2): 68-73.

Goulder, J., Simpson, M. and Tuson, J. (1995) Evaluation of the Implementation of the 5 - 14 Development Programme 1991 - 1995: Primary/Secondary Liaison: Secondary School's Perspectives. Aberdeen and Dundee: Northern College.

Inner London Education Authority (ILEA) (1984) Improving Secondary Schools: Report of the Committee on the Curriculum and Organisation of Secondary Schools chaired by Dr David Hargreaves (Hargreaves Report). London: ILEA

Jarman, R. (1997) 'Fine in Theory: A Study of Primary-Secondary Continuity in Science, Prior and Subsequent to the Introduction of the Northern Ireland Curriculum', Educational Research 39(3): 291-310.

Lance, A. (1994) 'The Case for Continuity’, Forum 36(2): 46-47.

National Foundation for Educational Research (NFER) (1995) Continuity and Progression 5 -16: Developments in Schools. Slough: NFER.

Nicholson, J. (1990) 'An Extended Project Looking at the Transfer of Pupils from Primary to Secondary Education’, Links Spring: 28-32.

Penney, D. (2001) ‘Planning for Progression’, PE and Sport Today 6: 18-22.

School Curriculum Assessment Authority (SCAA) (1996) Promoting Continuity between Key Stage 2 and Key Stage 3. London: SCAA.

Walsh, M.E. (1995) 'Rural Students’ Transition to Secondary Schools: Culture Curriculum and Context', Curriculum Journal 6: 115-127. 